Check for updates

Cite this: RSC Adv., 2019, 9, 22805

\title{
Linker length in fluorophore-cholesterol conjugates directs phase selectivity and cellular localisation in GUVs and live cells $\uparrow$
}

\begin{abstract}
Darragh O' Connor, (D) Aisling Byrne and Tia E. Keyes (D)*
Lipid membrane fluorescent probes that are both domain-selective and compatible with demanding microscopy methods are crucial to elucidate the presence and function of rafts and domains in cells and biophysical models. Whereas targeting fluorescent probes to liquid-disordered $\left(L_{d}\right)$ domains is relatively facile, it is far more difficult to direct probes with high selectivity to liquid-ordered $\left(L_{o}\right)$ domains. Here, a simple, one-pot approach to probe-cholesterol conjugation is described using Steglich esterification to synthesise two identical BODIPY derivatives that differ only in the length of the aliphatic chain between the dye and cholesterol. In the first, BODIPY-Ar-Chol, the probe and cholesterol were directly ester linked and in the second BODIPY-Ahx-Chol, a hexyl linker separated probe from cholesterol. Uptake and distribution of each probe was compared in ternary, phase separated giant unilamellar vesicles (GUVs) using a commercial $L_{d}$ marker as a reference. BODIPY-Ar-Chol targets almost exclusively the $L_{d}$ domains with selectivity of $>90 \%$ whereas by contrast introducing the $C_{6}$ linker between the probe and cholesterol drove the probe to $L_{\circ}$ with excellent selectivity (>80\%). The profound impact of the linker length extended also to uptake and distribution in live mammalian cells. BODIPY-Ahx-Chol associates strongly with the plasma membrane where it partitioned preferably into opposing micron dimensioned do-mains to a commercial $L_{d}$ marker and its concentration at the membrane was reduced by cyclodextrin treatment of the cells. By contrast the BODIPY-Ahx-Chol permeated the membrane and localised strongly to lipid droplets within the cell. The data demonstrates the profound influence of linker length in cholesterol bioconjugates in directing the probe.
\end{abstract}

Received 23rd May 2019

Accepted 14th July 2019

DOI: $10.1039 / c 9 r a 03905 h$

rsc.li/rsc-advances

\section{Introduction}

Lipid membranes of cells and their organelles are heterogenous and laterally organised into domains of different dimensions and composition. Amongst these, the existence and function of lipid rafts ${ }^{1,2}$ in particular, remains controversial..$^{3-5}$ Rafts are believed to be tightly packed but mobile, cholesterol and sphingolipid-enriched, nano-platforms of liquid ordered lipid domain that diffuse laterally within the plasma membrane. ${ }^{6}$ Lipid rafts are implicated in many important membrane-based functions, including protein trafficking and cell signaling. ${ }^{3,-10}$ They are often modelled in artificial membranes by using phase-separating lipid compositions containing sphingomyelin and cholesterol along with one or more low-melting phospholipid, to yield co-existing immiscible liquid phases. The two phases are liquid-disordered $\left(\mathrm{L}_{\mathrm{d}}\right)$ phase and liquid-ordered $\left(\mathrm{L}_{\mathrm{o}}\right)$ phase. The latter contains higher cholesterol (Chol) and

School of Chemical Sciences, National Centre for Sensor Research, Dublin City University, Glasnevin, Dublin 9, Ireland. E-mail: Tia.keyes@dcu.ie; Tel: +353 1 7008185

$\dagger$ Electronic supplementary information (ESI) available. See DOI: $10.1039 / \mathrm{c} 9 \mathrm{ra} 03905 \mathrm{~h}$ sphingolipid content than $\mathrm{L}_{\mathrm{d}}$ and is closer to a liquid-crystalline phase. The $L_{d}$ phase exhibits a higher degree of lateral fluidity than the $\mathrm{L}_{\mathrm{o}}$ phase which is more tightly packed and also less permeable than the $\mathrm{L}_{\mathrm{d}}$. Phase separated liposomes are widely used as models for raft behaviour in cell membranes, and the dimensions of the domains can be controlled by varying the identity and ratio of the lipid component. ${ }^{11}$ However, although domains can be imaged fairly readily in model systems such as liposomes, rafts are far harder to reliably detect within cells using conventional fluorescence microscopy, due to their putative size and dynamic nature. In particular, imaging domains within cell membranes is challenging because probes that work well with liposomes, typically do not remain at the membrane but internalise unpredictably into the interior of live cells.

Although important advances have been made in detection of rafts through label free methods, including for example, through interferometric scattering microscopy imaging (iSCAT), ${ }^{12}$ nano-secondary ion mass spectrometry nano (SIMS) ${ }^{13}$ and AFM. ${ }^{14}$ Fluorescence remains an key technique in many biophysical studies and probes that show phase partitioning can contribute to elucidation of domain structures. With recent advances in fluorescence 
microscopy, experiments that can directly monitor both temporally and dimensionally, rafts in cells, their organelles and associated models using fluorescence are within reach. ${ }^{15}$ However, such experiments require luminescent probes that are compatible with the demands of the method and are both capable of preferential partitioning into $L_{o}$ phases and in the case of live cells, of remaining localised at the membrane. There are relatively few probes that favour, with high specificity the $\mathrm{L}_{\mathrm{o}}$ region. The majority of probes that show phase preference, partition into the liquid disordered $\left(\mathrm{L}_{\mathrm{d}}\right)$ phase. The most selective $\mathrm{L}_{\mathrm{o}}$ partitioning probes reported, are based on polycyclic aromatic hydrocarbons. ${ }^{16-19}$ whose planarity presumably permits intercalation into the tightly packed $\mathrm{L}_{\mathrm{o}}$ lipid/sterol structure. Fluorescent cholesterol analogues have also been widely explored as fluorescent probes that favour the $\mathrm{L}_{\mathrm{o}}$ phase. The fluorescent derivative cholestatrienol, for example, has been successfully used to probe membrane formation and structure, ${ }^{19}$ cholesterol trafficking ${ }^{20}$ and sterol binding within human genes. ${ }^{21}$ NBD-cholesterol and its derivatives have demonstrated lipid domain detection in both cells and models $^{22}$ and cholesterol distribution tracking in model membranes. ${ }^{23}$ However, across PAHs and cholesterol analogues, the fluorophore excitation/emission is in the ultraviolet (UV)/blue spectral region, ${ }^{19}$ which typically is unsuitable for super-resolution imaging or correlation spectroscopy and there is limited opportunity for tuning their photochemical or photophysical properties without reducing their co-planarity. Non-PAH probes have been successfully driven to the $\mathrm{L}_{\mathrm{o}}$ by appendage of a raft associating sterol or lipid, but discrimination typically, does not approach that achieved for $\mathrm{L}_{\mathrm{d}}$ labelling. ${ }^{21}$

The 4,4-difluoro-4-bora-3a,4a-diaza-s-indacene (BODIPY) derivatives are excellent luminophores for bioimaging ${ }^{22,23}$ with outstanding photophysical characteristics including sharp absorbance and emission features, high extinction coefficients, large quantum yields and photochemical robustness. ${ }^{24-27}$ For these reasons, they have been widely applied to lipid membrane labelling in both artificial models and live cells..$^{28-34}$ Furthermore, due to the synthetic versatility of the BODIPY core and it's meso positions it is amenable to bioconjugation. This has led to diverse families of BODIPY dyes that have found application in biological labelling. ${ }^{35-39}$ Lipid tails or cholesterol have also been applied to the BODIPY to improve cell uptake $e^{40-42}$ or to label lipid membranes. ${ }^{21,43}$ The lipophilicity of the BODIPY core and its small size makes it attractive in this regard and indeed a number of BODIPY lipid conjugates are offered commercially for bio-imaging; for example, BODIPY FL C5-GM1, BODIPY PC and TopFLuor® BODIPY.

BODIPY modified with cholesterol and ganglioside GM1 have been applied as $\mathrm{L}_{\mathrm{o}}$ membrane probes. ${ }^{44}$ However, where they have shown tendency to sequester into both domains they have been domain sensitive rather than selective, where $L_{o}$ discrimination is on basis of domain order or lifetime rather than selectivity. ${ }^{18,45-47}$

Such a complex was reported Kuimova et al. ${ }^{48}$ where appendage of a cholesterol to phenyl-BODIPY via $\mathrm{a}_{3}$ linker saw some partitioning into the $\mathrm{L}_{\mathrm{o}}$ domain. As the parent phenylBODIPY partitions only to the $\mathrm{L}_{\mathrm{d}}$ we were interested to see if incorporating additional carbons to the linker between the Chol and the probe might permit the Chol to localise at the $\mathrm{L}_{\mathrm{o}}$. If the distance was extended the hydrophobic BODIPY might then orient at the partially hydrated boundary of bilayer core and hydrophilic interface. Comparing a directly linked cholesterol probe and analogue separated by a 6-carbon chain between cholesterol and phenyl BODIPY we observed that the former localizes at the $\mathrm{L}_{\mathrm{d}}$ while the latter shows strong preference for the $\mathrm{L}_{\mathrm{o}}$. The probes were prepared using a novel approach to cholesterol conjugation exploiting a one-step Steglich esterification which is very mild and less arduous than reported methods and should be widely applicable for cholesterol conjugation. Importantly, we found that the $\mathrm{C}_{0}$ cholesterol probe was internalised into the cell, whereas the $\mathrm{C}_{6}$ conjugate was retained at the living cell membrane where it appears to stain sterol-rich membranes distributing in a mutually exclusive way to $\mathrm{L}_{\mathrm{d}}$ probe DiD.

\section{Results and discussion}

\section{Preparation of cholesterol conjugates}

Scheme 1 illustrates the chemical structures and route to synthesis of the BODIPY-cholesterol conjugates. Cholesterol was appended to a BODIPY core via Steglich esterification either directly through the pendant carboxyl group or via a $\mathrm{C}_{6}$ linker appended to the acid. Detailed synthetic protocols are described in the Experimental section. In brief, precursor BODIPY-Ar-COOH (1), ${ }^{49}$ was reacted with dimethylaminopyridine (1 equiv.), $\quad N, N^{\prime}$-dicyclohexylcarbodiimide (DCC) (1.1 equiv.) and cholesterol (2 equiv.) in DCM to yield BODIPY-Ar-Chol (2) at 38\% yield after chromatographic purification.

4-Formylphenyl-Ahx (4) was prepared by amide coupling of 4formylbenzoic acid and 6-aminohexanoate, which was then hydrolysed to give 4 . Condensation of 4 with 2,4-dimethylpyrrole (2.2 equiv.) yielded BODIPY-Ahx (5). The cholesterol derivative BODIPY-Ahx-Chol (6) was then simply prepared in $40.2 \%$ yield using the same esterification method as 2 . Structural characterisation was carried out using high-resolution mass spectrometry, ${ }^{1} \mathrm{H}$ and ${ }^{13} \mathrm{C}$ NMR spectroscopy and can be found in the ESI. $\dagger$

\section{Conjugate photophysical characterisation}

Fig. S15 $\uparrow$ shows the absorbance and emission profiles of BODIPY-Ar-Chol and BODIPY-Ahx-Chol in dichloromethane, chloroform, acetonitrile and methanol. Both derivatives exhibit the $\mathrm{S}_{0}-\mathrm{S}_{1}\left(\pi-\pi^{*}\right)$ transition centred at $500 \pm 3 \mathrm{~nm}$, and as expected, behaviour is nearly identical for both fluorophores across solvents. ${ }^{50}$ Emission shifts to the red with decreasing dielectric constant, with the exception of BODIPY-Ahxcholesterol in acetonitrile which exhibited a slight red-shift compared to dichloromethane. BODIPY-Ar-Chol is insoluble in water whereas BODIPY-Ahx-Chol is weakly soluble but emission is extinguished in this medium. 


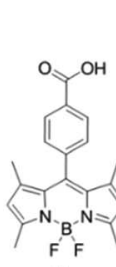

1

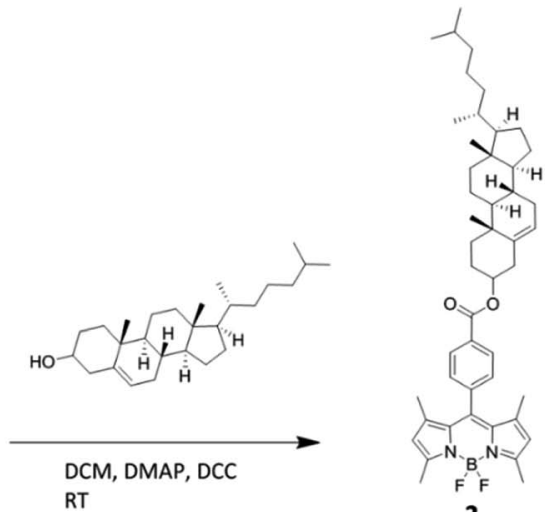

2
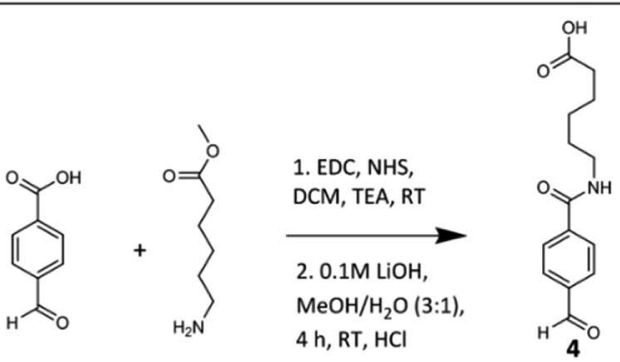
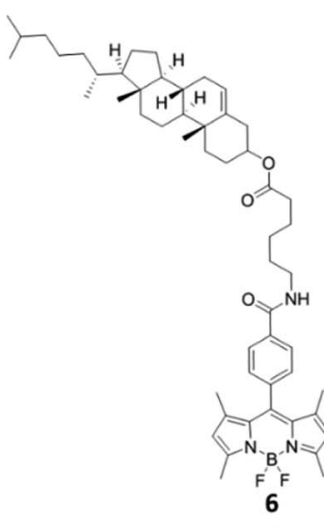

DCM, DMAP, DCC

RT

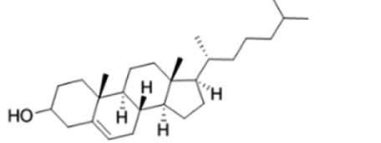

Scheme 1 Synthesis of BODIPY-cholesterol conjugates, BODIPY-Ar-Chol (2) and BODIPY-Ahx-Chol (6).

Such behaviour, observed previously, in BODIPY derivatives, maybe due to aggregation induced quenching. ${ }^{51}$ Both compounds exhibit intense emission in organic media with quantum yields of $\sim 40 \%$ or greater with the exception of methanol where the quantum yield falls below $40 \%$ for both compounds. Interestingly, BODIPY-Ahx-Chol shows consistently higher quantum yields across all solvents of the two compounds. And, correspondingly, BODIPYAr-Chol has a shorter fluorescence lifetime that decreases with increasing solvent polarity. The shortest lifetime for both compounds was in methanol, where $\tau$ is $2.25 \pm 0.04$ and $2.68 \pm$ 0.002 , whereas the longest lifetime was in chloroform, $\tau$ is $2.94 \pm$ 0.002 and $3.27 \pm 0.005$ respectively. Photophysical data is summarised in Table 1.

\section{Partitioning and photophysics in giant unilamellar vesicles}

Although widely distributed in the cell membrane, cholesterol is well-established as an essential component of detergent resistant membrane domains in cells and by extension in lipid rafts. $^{52}$

In model membranes, cholesterol has been shown to promote formation of $\mathrm{L}_{\mathrm{o}}$ domains and partitions with greater preference into these domains than the $\mathrm{L}_{\mathrm{d}} \cdot{ }^{53,54}$ The origin of cholesterol preference for $\mathrm{L}_{\mathrm{o}}$ and its condensing effect on the membrane has been discussed widely in the literature. ${ }^{5,56}$ The 'umbrella model' described by Huang and Feigenson ${ }^{57}$ proposes cholesterol is shielded from unfavourable aqueous interaction by the headgroups of adjacent phospholipids which act as

Table 1 Summary of photophysical data ${ }^{a}$

\begin{tabular}{lllllllr}
\hline & Solvent & $\lambda_{\text {abs }}(\mathrm{nm})$ & $\lambda_{\mathrm{em}}(\mathrm{nm})$ & $\varepsilon\left(\mathrm{M}^{-1} \mathrm{~cm}^{-1}\right)$ & $\phi_{\mathrm{fl}}$ & $\tau_{\text {lum }}(\mathrm{ns})$ & Dielectric constant $\left(\varepsilon_{\mathrm{r}}\right)$ \\
\hline \multirow{2}{*}{ BODIPY-Ar-Chol } & Dichloromethane & 501 & 513 & 63460 & 0.40 & $2.85 \pm 0.008$ & 8.93 \\
& Chloroform & 503 & 516 & 55484 & 0.45 & $2.94 \pm 0.002$ & 4.81 \\
& Acetonitrile & 498 & 511 & 49335 & 0.39 & $2.39 \pm 0.009$ & 36.6 \\
& Methanol & 498 & 513 & 44372 & 0.31 & $2.25 \pm 0.04$ & 32.6 \\
BODIPY-Ahx-Chol & Dichloromethane & 501 & 513 & 64345 & 0.50 & $3.10 \pm 0.001$ & 8.93 \\
& Chloroform & 503 & 518 & 102646 & 0.46 & $3.27 \pm 0.005$ & 4.81 \\
& Acetonitrile & 497 & 516 & 64332 & 0.43 & $2.98 \pm 0.001$ & 36.6 \\
& Methanol & 498 & 513 & 54070 & 0.39 & $2.68 \pm 0.002$ & 32.6
\end{tabular}

${ }^{a}$ All solutions were measured at concentrations of $10 \mu \mathrm{M}$. Slit widths for emission were set to $2.5 \mathrm{~nm}$. Lifetime data was recorded in triplicate. Quantum yields were measured using fluorescein $0.1 \mathrm{M} \mathrm{NaOH}(\Phi=0.90)^{20}$ as standard. 
'umbrellas'. Increasing cholesterol content causes reorientation of the phospholipids resulting in a more tightly packed and rigid bilayer. For sphingomyelin containing compositions, $\mathrm{H}$ bonding interactions of cholesterol with SM are also thought to play a role in phase preference. In principle, this preference makes cholesterol an attractive appendage to drive labels to the $\mathrm{L}_{\mathrm{o}}$ domains of phase separated membranes. But, conjugation of bulky fluorophore to cholesterol can prevent proper insertion and block e.g. H-bonding interactions or shielding between the cholesterol and adjacent phospho- and sphingolipids due to steric or electrostatic interference. In order to investigate whether such steric affects could be overcome by extending a lipophilic alkyl spacer between the Chol and probe we introduced $\mathrm{C}_{6}$ linker between cholesterol and fluorophore (6 in Scheme 1) and compared the phase distribution of this probe with one in which the cholesterol was directly ester linked to the probe carboxyl ( 2 in Scheme 1). It is worth noting that by conjugating a cholesterol onto a fluorophore via the lone hydroxyl group it is unlikely that the fluorescent cholesterol derivatives will have the same characteristics of cholesterol especially behaviour at the bilayer interface, where typically the hydroxyl group is most exposed at the interface.

To evaluate the phase distribution of each derivative, electroformed, phase-separated GUVs of composition DOPC/BSM/ Chol (4:4:2 mol\%), were incubated with BODIPY-Ar-Chol and DiD or BODIPY-Ahx-Chol and DiD. The resulting structures were imaged using confocal fluorescence microscopy (Fig. 1). Notably, each probe distributed preferentially into the opposing phase. To identify the $\mathrm{L}_{\mathrm{d}}$ phase, DiD a commercial $\mathrm{L}_{\mathrm{d}}$ probe was included at a concentration of $0.1 \mathrm{~mol} \%$ of lipid content prior to electroformation. ${ }^{19}$ In separate studies (ESI Fig $\mathrm{S} 16 \dagger$ ) we confirmed that there is no cross-talk between DiD and the BODIPY probes. Fig. 1A-C shows that BODIPY-Ar-Chol partitions almost exclusively into the $\mathrm{L}_{\mathrm{d}}$ phase of the GUVs, where it co-localises with DiD. Remarkably, Fig. 1D-F shows that BODIPY-Ahx-Chol associates preferentially to the $\mathrm{L}_{\mathrm{o}}$ domains, where DiD is absent. The oppositional partitioning of the two probes is reflected also in the intensity profiles shown in Fig. 1H. As discussed below, the probes show within experimental error, negligible difference in quantum yield when localised at $\mathrm{L}_{\mathrm{o}}$ or $\mathrm{L}_{\mathrm{d}}$, we can assume that the fluorescence quantum yield is unaffected by phase. On this basis we can roughly approximate the $\mathrm{L}_{\mathrm{o}}$ partitioning on the basis of intensity for BODIPY-Ahx-Chol as (\% $\mathrm{L}_{\mathrm{o}} \sim 80 \%$ ) (ESI Fig. S23 $\dagger$ ) and the BODIPY-Ar-Chol partitioned to the $\mathrm{L}_{\mathrm{d}}$ at $\sim 90 \%$. The former may be an overestimate of BODIPY-Ahx-Chol $\mathrm{L}_{\mathrm{o}}$ association, as although lifetimes are unchanged, $x y$ scans of $\mathrm{L}_{\mathrm{o}}$ and $\mathrm{L}_{\mathrm{d}}$ associating probes in liposomes, prepared under the same probe concentrations suggest the probe at the $\mathrm{L}_{\mathrm{o}}$ probe is slightly brighter than the $\mathrm{L}_{\mathrm{d}}$.

The GUVs were imaged by fluorescence lifetime imaging (FLIM) to evaluate the effect of domain on probe photophysics. As described, in solution, emission from both probes fit to mono-exponential decay kinetics. On partitioning into the lipid membrane of the GUVs, the BODIPY emission decayed according to a biexponential model irrespective of the phase into which the probe partitioned. The lifetime data is summarised in Table 2. The short component of the decay was within experimental error the same for both probes at $1.7 \mathrm{~ns}$ constituting 30 to $40 \%$ of the amplitude of the decay. Its origin is unclear but similar effects have been noted previously in membrane bound probes and particularly molecular rotors attributed to a fraction of probe that is associated/oriented at the liposomes in such a way that it is strongly exposed to the less viscous membrane interface. ${ }^{48}$ The dominant component of the decay ( $>50 \%$ of the amplitude for both probes) was longer lived. For BODIPY-Ar-Chol fluorescence lifetime was determined as $4.74 \mathrm{~ns}$ from the $\mathrm{L}_{\mathrm{d}}$ phase. By comparison for BODIPY-Ahx-Chol, localised at the $\mathrm{L}_{\mathrm{o}}$, the long component of the lifetime was recorded as 4.92 ns (Fig. 2). The decay was confirmed from the $\mathrm{L}_{\mathrm{o}}$, by labelling with DID.

Recalling that in chloroform BODIPY-Ar-Chol and BODIPY-Ahx-Chol exhibit emission decays of 2.94 and 3.27 respectively. Both dyes show a significant increase in emission lifetime on association with GUV attributed to the membrane rigidity/increased micro-viscosity. Similar behaviour has been reported in other probes incorporated into liposomes. ${ }^{\mathbf{1 8 , 4 6 , 5 8}}$

Because of the very high selectivity of each probe for their respective phases, we were unable to obtain reliable lifetime data from FLIM for the probes in the opposing phases. However, in previous reports, where probe associates with $\mathrm{L}_{\mathrm{o}}$ as well as at $\mathrm{L}_{\mathrm{d}}$ domains, it has been noted that the increased lipid order/rigidity of the $\mathrm{L}_{\mathrm{o}}$ often reduces non-radiative decay to a greater extent than in $\mathrm{L}_{\mathrm{d}}$ leading to notably longer emission lifetimes from this domain. ${ }^{19}$ In a BODIPY cholesterol probe linked through a $\mathrm{C}_{2}$ linker Heikal et al. reported that the probe partitioned into both $\mathrm{L}_{\mathrm{o}}$ and $\mathrm{L}_{\mathrm{d}}$ phases and that the lifetime was longer from the $\mathrm{L}_{\mathrm{o}}$, with FLIM results also indicating a stronger preference for $\mathrm{L}_{\mathrm{o}}$ domains. ${ }^{46}$

Thus, one might have expected a significant increase in lifetime of $\mathrm{L}_{\mathrm{o}}$ associated BODIPY-Ahx-Chol given that its emission is already notably longer lifetime in chloroform than BODIPY-Ar-Chol.

The negligible difference observed between BODIPY-Ar-Chol in the $\mathrm{L}_{\mathrm{d}}$ and BODIPY-Ahx-Chol in the $\mathrm{L}_{\mathrm{o}}$ thus seems initially counter-intuitive. However, we speculate that the similarity in lifetimes between each probe in opposing phases arises because the BODIPY unit cannot intercalate deeply into $\mathrm{L}_{\mathrm{o}}$. It associates only when the linker is long enough between the cholesterol anchor and the fluorophore, to allow the cholesterol to partition while the probe orients at the interface of the bilayer with shallow penetration where photophysics are not strongly impacted by the rigidity of the $\mathrm{L}_{\mathrm{o}}$ domain.

\section{Cell studies}

Cell membranes contain cholesterol and sphingolipid enriched microdomains, that are resistant to non-ionic detergent solubilisation. These detergent-resistant membranes (DRMs) have many of the characteristics of the liquid-ordered $\left(\mathrm{L}_{\mathrm{o}}\right)$ phase in model membranes. Given the strong selectivity of BODIPY-AhxChol probes for $\mathrm{L}_{\mathrm{o}}$ domains in GUVs, we investigated if this phase preference extended to its distribution in living cells and 

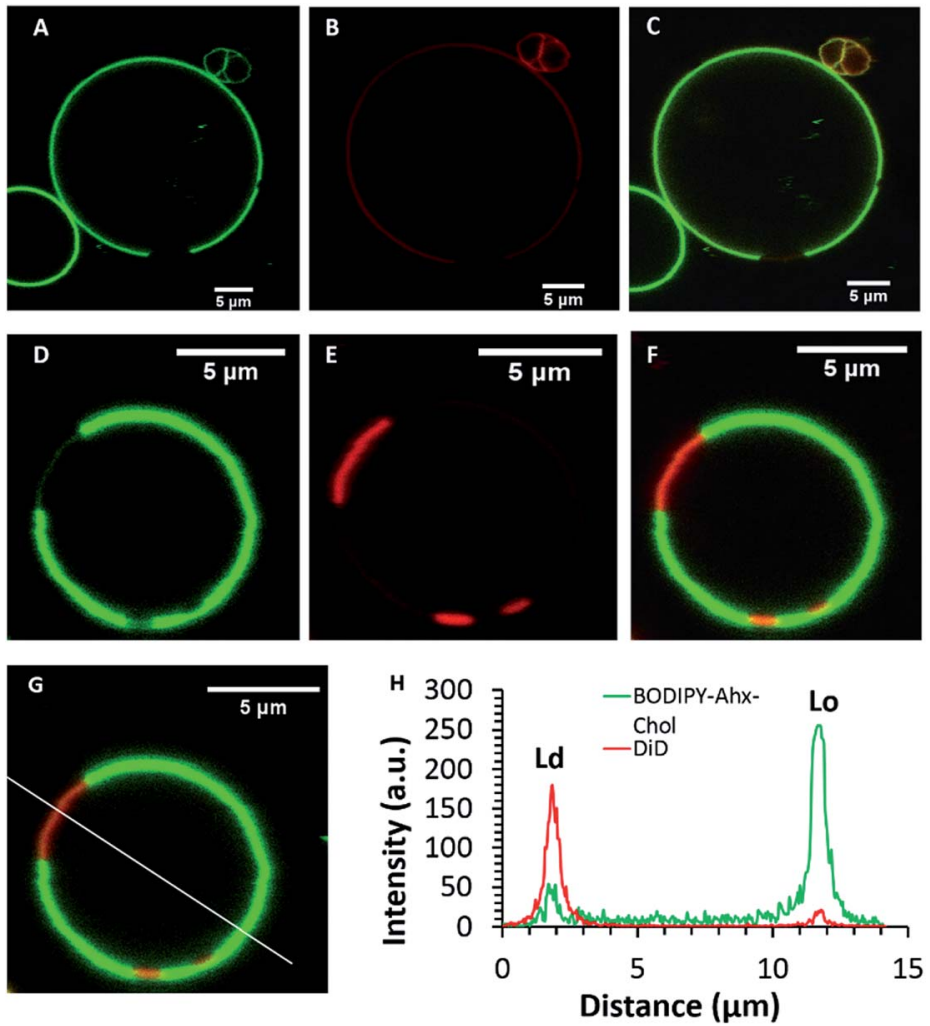

Fig. 1 Confocal fluorescent imaging of phase separated GUVs DOPC/BSM/Chol (4:4:2) mol\%. GUV stained with compound BODIPY-Ar-Chol $(A), D i D(B)$ and overlay image (C). GUV stained with BODIPY-Ahx-Chol (D), DiD (E) and overlay image (F). Figures (A-F) are raw data images, without pre-processing. Fluorescence intensity plot of BODIPY-Ahx-Chol (-) vs. DiD (-) (G and H). Fluorescent lifetime image of BODIPY-AhxChol(I) in a phase separated GUV of composition DOPC/BSM/Chol $(4: 4: 2)$ with variation in lifetimes given by the colour bar. Fluorescent lifetime image of the difference in lifetime given by colour $\left(L_{d}\right.$ region $=$ orange/yellow) and ( $L_{\circ}$ region $=$ green). A $503 \mathrm{~nm}$ white light laser was used to excite the GUV samples and the emission collected between 511-570 nm.

if we could distinguish membrane domain distributions in a cancer and non-cancer cell line.

Fig. 3 shows confocal fluorescence images of live HeLa and CHO cells following their incubation with BODIPY-Ahx-Chol (5 $\mu \mathrm{M})$ at $37{ }^{\circ} \mathrm{C}$ for $3 \mathrm{~h}$. The imaging indicates that the probe localises at the plasma membranes. From $z$-scanning it is evident that BODIPY-Ahx-Chol also permeates the cell as emission can be seen from membranous regions therein, but it is excluded from the nucleus. To examine BODIPY-Ahx-Chol distribution in the membrane we focused on the lower cell membrane which is intensely but highly heterogeneously fluorescent. ${ }^{59-61}$ In HeLa cells (Fig. 3A and B) discontinuous patches of sub-200 $\mathrm{nm}$ to $1 \mu \mathrm{m}$ length as well as more ordered ringed structures are intensely fluorescently labelled. However, in addition dark, unlabelled regions of comparable dimensions (white arrows) are evident across the membrane. On co-staining cells with DiD (800 nM) it was observed that, as at GUVs, BODIPY-Ahx-Chol and DiD distributed in a mutually exclusive way in the cell membrane. This is most obvious in HeLa cells where Fig. $4 \mathrm{~A}-\mathrm{C}$ shows that DiD localises in the regions of the cell membrane from where BODIPY-Ahx-Chol is excluded (ESI Z-Stack Video $\dagger$ ).

The membranes of live cells are so complex that it is difficult to ascertain definitively what is labelled. Given the propensity

Table 2 Fluorescent lifetime of BODIPY-Ar-Chol and BODIPY-Ahx-Chol within phase separated GUVs containing both liquid-disordered and liquid-ordered domains, as well as live HeLa cells

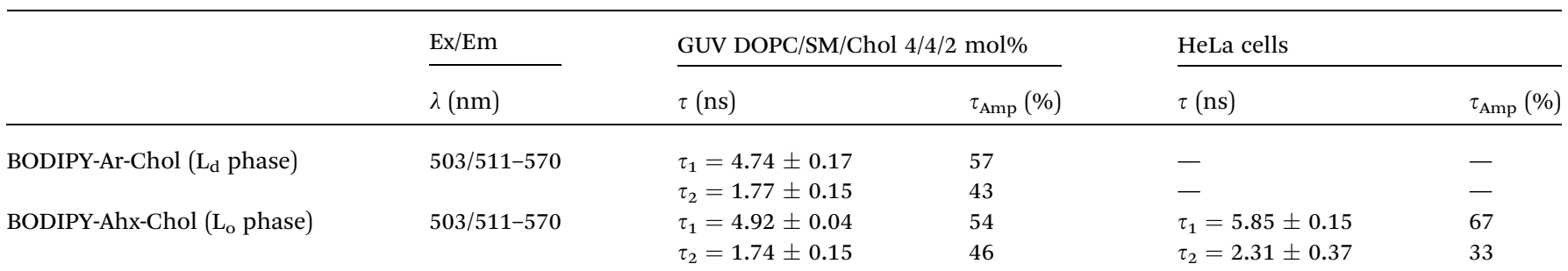



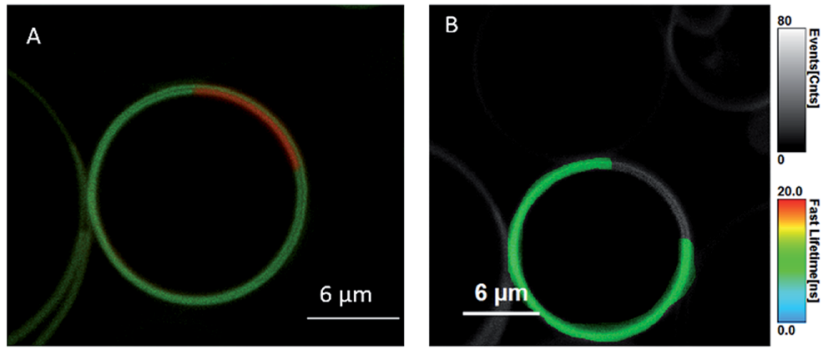

Fig. 2 Confocal fluorescent image of a phase separated GUV of composition DOPC/BSM/Chol (4:4:2 mol\%) co-stained with BODIPY-Ahx-Chol (green) and DiD (red) showing the different $L_{d}($ red) and $L_{\circ}$ phases (green) (A). Fluorescent lifetime image (FLIM) of the same GUV showing BODIPY-Ahx-Chol in the $\mathrm{L}_{\circ}$ phase (B).
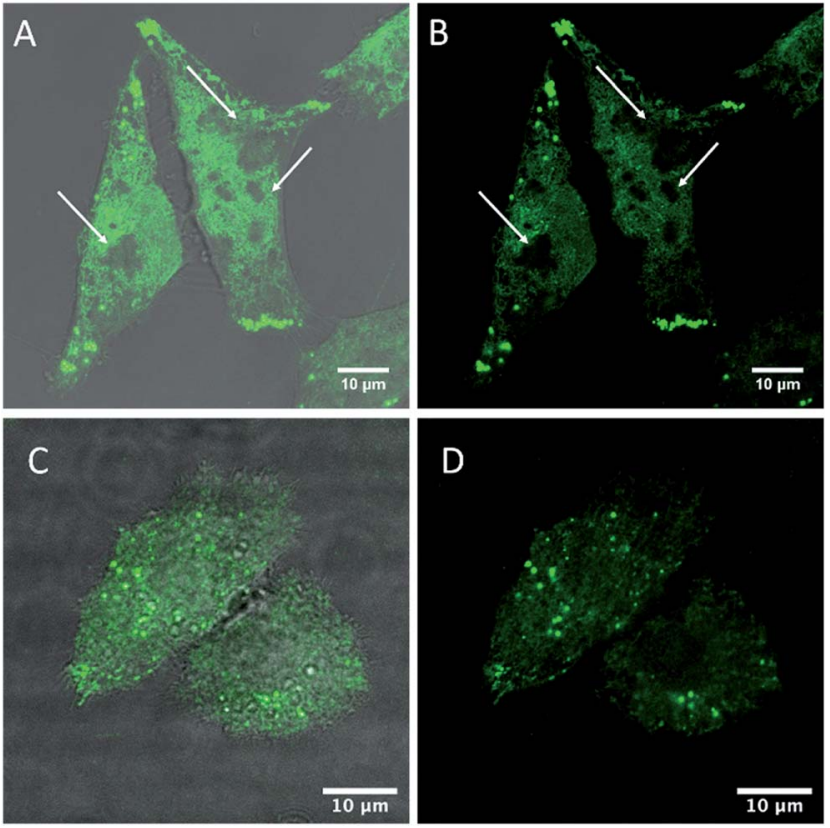

Fig. 3 Live HeLa ( $\mathrm{A}$ and $\mathrm{B}$ ) and $\mathrm{CHO}$ cells ( $\mathrm{C}$ and $\mathrm{D})$ stained with BODIPY-Ahx-Chol $\left(5 \mu \mathrm{M}, 3 \mathrm{~h} 37^{\circ} \mathrm{C}\right)$. White arrows highlighting the dark regions where BODIPY-Ahx-Chol does not localise. (A) and (C) overlay of BODIPY-Ahx-Chol and background channels. (B) and (D) BODIPY-Ahx-Chol channel.

for the probe to stain sterol-rich domains/regions and the fact that DiD is excluded from many of the regions that BODIPYAhx-Chol is localised suggests it is localizing at sterol-rich domains. This may include $\mathrm{L}_{\mathrm{o}}$ phases as well as caveolae at the cell membrane, protein aggregated domains and membrane bound protein. The staining is highly heterogenous and structured, over a range of sizes, that are difficult to resolve with confocal imaging. ${ }^{60}$ Interestingly, when incubated with BODIPY-Ahx-Chol under identical conditions, $\mathrm{CHO}$ cells did not show the same distribution as shown in Fig. 3C and D. The probe emission from the membrane is weaker but appears to distribute more homogenously across the membrane with less well defined bright and dark regions. Staining of lipid droplets are evident as intense spherical features, in both CHO and HeLa
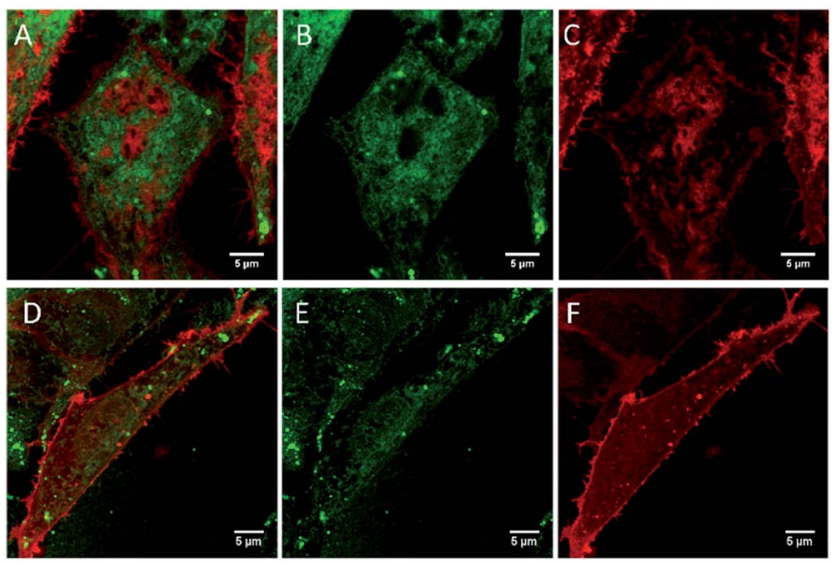

Fig. 4 Live HeLa $(A-C)$ and $C H O$ cells $(D-F)$ stained with BODIPYAhx-Chol and co-stained with DiD, (800 nM). Overlay of channels (A and $\mathrm{D})$, the BODIPY-Ahx-Chol channel in green (B and $\mathrm{E}$ ) and the DiD channel in red ( $C$ and $F$ ).

images, this was confirmed from $z$-scanning which showed the features persisted outside the membrane.

The difference between probe distribution we attribute to different membrane compositions between the two cell lines as HeLa is a cancer line and CHO a mammalian non-cancer line. The cholesterol concentration within the cell membrane is highly regulated and has been shown to be significantly upregulated in many cancers leading to increased lipid order, and caveolae are often highly prevalent in cancer cell lines. In particular, detergent resistant/raft-like domains have been shown to be particularly prevalent in multidrug resistant cancer cell lines. ${ }^{62-64}$ The distinctive membrane compositions lead to greater lipid order in the HeLa membrane compared to CHO. Of note, for BODIPY-Ar-Chol in the absence of the $\mathrm{C}_{6}$ linker, the probe shows markedly different uptake and distribution. In both HeLa and CHO cells it permeates the membrane and localises with high selectively into lipid droplets (Fig. S19 ESI $\dagger$ ). When co-stained with DiD, and focusing on the plasma membrane of the cell, no emission from BODIPY-Ar-Chol could be observed (Fig. S20 ESI $\dagger$ ), confirming that without the linker, the complex does not localise in the plasma membrane in live cells.

\section{Probing cholesterol in the cell membrane}

In order to understand further if the BODIPY-Ahx-Chol localises in cholesterol-rich domains at HeLa and CHO cells, we examined if the presence of cholesterol in the membrane affected dye distribution. This was achieved by treating the cells with methyl- $\beta$-cyclodextrin (M $\beta \mathrm{CD}$ ) which is widely used for cholesterol depletion from the plasma membrane, as it forms soluble host-guest inclusion complexes with cholesterol with high affinity. ${ }^{46,65}$ It can also deplete lipids from the membrane but typically to a significantly lower extent than cholesterol. ${ }^{66}$ Cells were initially exposed to $\mathrm{M} \beta \mathrm{CD}(10 \mathrm{mM})$ for 1 hour in cell media, then removed and washed prior to adding the BODIPYAhx-Chol $(5 \mu \mathrm{M})$ to the cells. Following probe exposure, the cells were washed and imaged without fixing. Fig. 5A and B show 
HeLa cells after $2 \mathrm{~h}$ exposure to M $\beta \mathrm{CD}$ stained with BODIPYAhx-Chol. Focusing on the lower plasma membrane of the cell as before, after 2 hours, emission is still observed from the membrane and dark/unstained regions are remain visible, similar to the non-cholesterol depleted cells (Fig. 3A and B) however emission overall is less intense, and heterogeneity of the emission is much less defined.

Furthermore, emission for BODIPY-Ahx-Chol also appears to have migrated to the plasma membrane periphery, with bright spots located along the cell membrane. A similar pattern of behaviour has been reported for other ordered-domain sequestering probes upon cholesterol depletion with $\mathrm{M} \beta \mathrm{CD} .{ }^{67}$ After $4 \mathrm{~h}$ of $\mathrm{M} \beta \mathrm{CD}$ cholesterol depletion, the dark regions completely disappear, and the emission intensity of BODIPYAhx-Chol although more homogeneously distributed has decreased (4.6 a.u. to 3.3 a.u. intensity), shown in Fig. 5E and F.

Overall, our data suggests that BODIPY-Ahx-Chol uptake to the cell membrane is greater at the cholesterol rich cell membrane of HeLa cells and that the probe associates in part with cholesterol rich domains at the membrane HeLa cells. The distribution observed here is also similar to that reported by Malim et al. ${ }^{68}$ and Yoshida et al. ${ }^{69}$ at HeLa cells. And, is consistent with literature where between 50 and $80 \%$ of cell membranes have been shown on the basis of detergent solubilisation resistance or fluorescence polarisation to be cholesterol rich raft-like domains. ${ }^{\mathbf{8} 70}$

In the case of $\mathrm{CHO}$ cells, treatment with $\mathrm{M} \beta \mathrm{CD}$ appears to have the opposite effect, where emission intensity Fig. 5G and $\mathrm{H}$ from the $\mathrm{CHO}$ membrane post treatment (3.9 a.u. to 6.9 a.u. intensity) increases. It is not clear why behaviour in the two cell lines on cholesterol depletion is so different, but our observations concur with data reported by Hao et al. ${ }^{67}$ who observed similar behaviour in CHO cells, that they speculated might be due coalescence of cholesterol bounded domains into microdomains on CD treatment.

Fluorescent lifetime imaging was carried out to evaluate the lifetime of BODIPY-Ahx-Chol from within live cells to gain further insight into the probe distribution in the membrane. Fig. 6 show the false-color FLIM images of the lifetime distributions within the cell.

The fluorescent decay in cells fit to a bi-exponential decay, although in some cases a third component of the fit (lifetime < $70 \mathrm{ps)}$ was required to account for autofluorescence/ background scatter (Table $\mathrm{S} 1 \dagger$ ). The majority of the longerlived components comes from the membrane structures, and notably, BODIPY-Ahx-Chol has a slightly longer lifetime of 5.85 ns in HeLa cells (A) compared to 5.3 ns in CHO cells (B). This is consistent with the higher content of cholesterol at the HeLa membrane which may contribute different phase distributions within the membrane. Comparing these lifetimes to those derived from GUVs, the longer lifetime of $4.9 \mathrm{~ns}$ is shorter than that observed in cells presumably reflecting the far greater complexity of the cell membrane, its diversity of lipids and roughly $50 \%$ protein at the membrane interface. Interestingly, after exposure to $\mathrm{M} \beta \mathrm{CD}$, the longer-lived component of $5.85 \mathrm{~ns}$ in HeLa cells decreases to $5.35 \mathrm{~ns}$ while the shorter component of $2.31 \mathrm{~ns}$ is not affected.

However, in CHO cells, the lifetime of the major component increases post M $\beta C D$ treatment (Table S1†). This data reflects the confocal images where in $\mathrm{CHO}$ cells the lipid regions appear to cluster together upon cholesterol redistribution, this is not observed for HeLa cells. For HeLa cells, the majority of the longlived component continues to arise from the membrane post $\mathrm{M} \beta \mathrm{CD}$ treatment, and the shorter lifetime of $2.23 \mathrm{~ns}$ is attributed to lipid droplet structures from inside the cells, which was observed in both confocal and FLIM images (Fig. 6C).
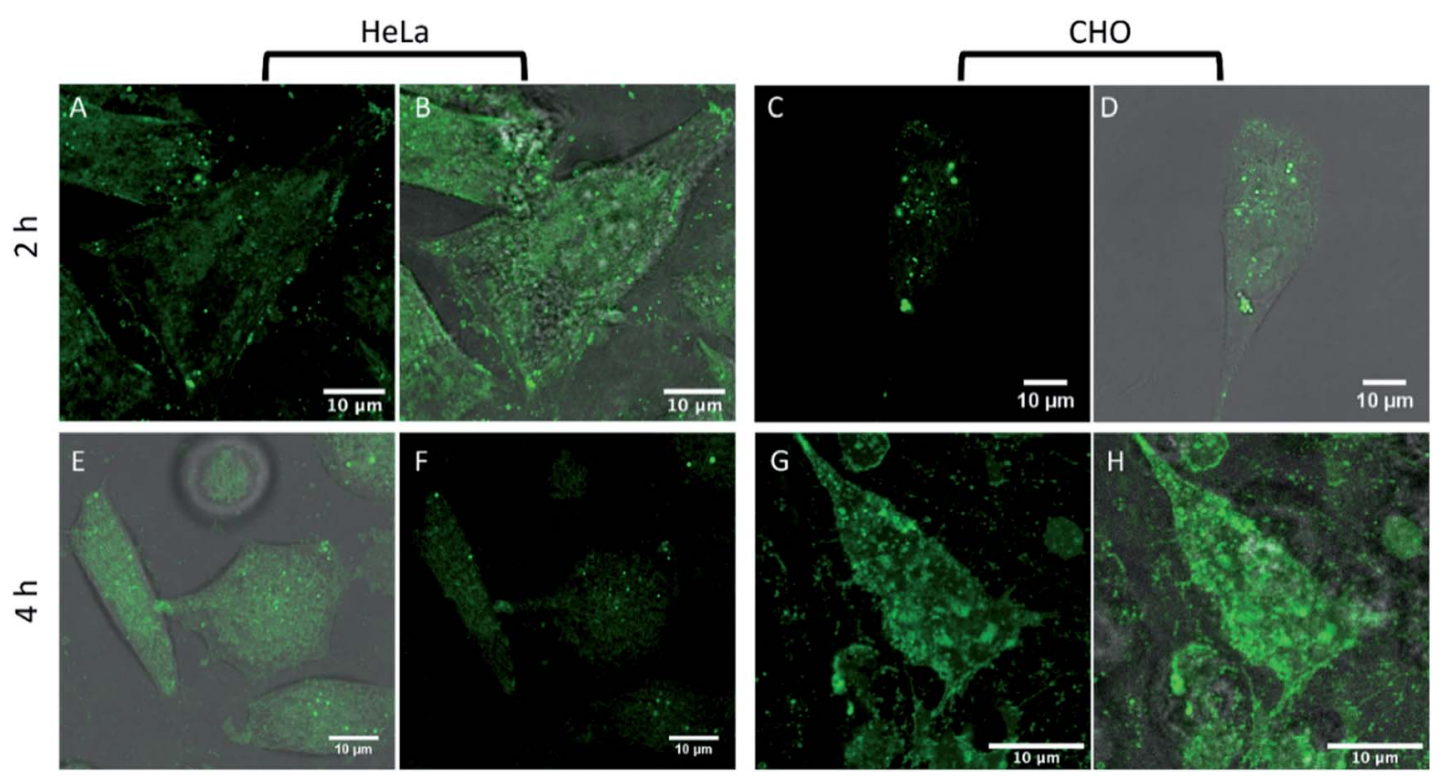

Fig. 5 Live HeLa and $\mathrm{CHO}$ cells treated with M $\beta C D$. Cells were treated with $10 \mathrm{mM} \mathrm{M \beta CD}$ and after $2 \mathrm{~h}((\mathrm{~A}$ and $\mathrm{B}) \mathrm{HeLa},(\mathrm{C}$ and $\mathrm{D}) \mathrm{CHO})$ and $4 \mathrm{~h}$, altering the cholesterol distribution in HeLa cells (E and F) and CHO cells ( $G$ and $H)$. (A), (C), (E) and (G) showing the BODIPY-Ahx-Chol channel, and (B), (D), (F) and (H) showing the overlay of BODIPY-Ahx-Chol and background channels. 

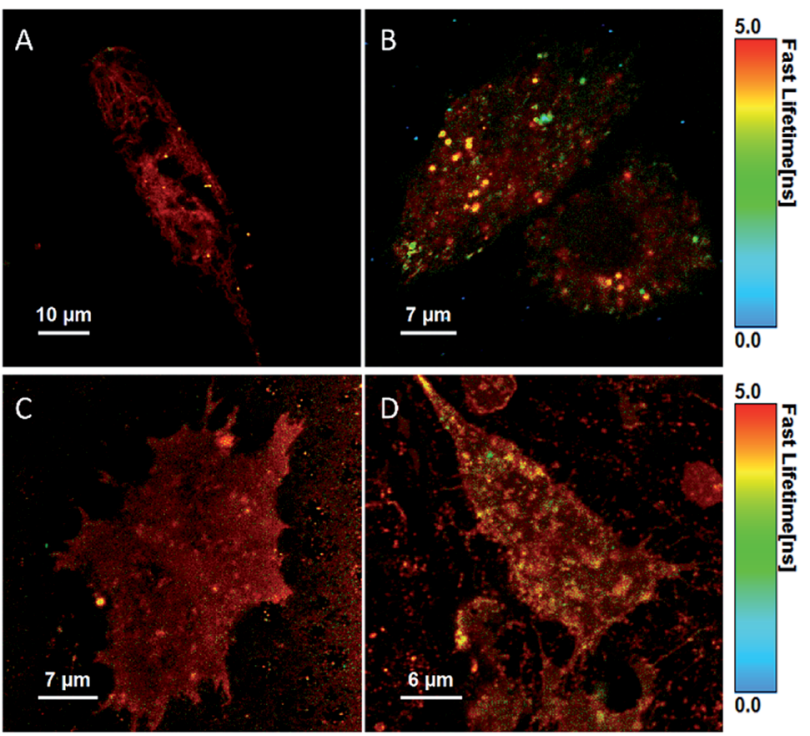

Fig. 6 Fluorescent lifetime images (FLIM) of a live HeLa cell (A) and $\mathrm{CHO}$ cell (B) stained with BODIPY-Ahx-Chol ( $5 \mu \mathrm{M}, 2 \mathrm{~h})$, and after treatment with $M \beta C D(10 \mathrm{mM})$ in HeLa (C) and $\mathrm{CHO}(\mathrm{D})$ cells.

\section{Conclusions}

We demonstrate a simple approach by which phase preference of a simple BODIPY fluorophore can be switched between $\mathrm{L}_{\mathrm{o}}$ or $\mathrm{L}_{\mathrm{d}}$ at phase forming liposomes, by altering the number of carbons in the alkyl linker separating probe from cholesterol. The cholesterol conjugation is achieved via a simple and very mild Steglich esterification reaction between probe carboxyl and cholesterol hydroxyl. Phase preference in domain forming giant unilamellar vesicles (GUVs) confirmed, using a commercial $\mathrm{L}_{\mathrm{d}}$ marker as reference, $>90 \% \mathrm{~L}_{\mathrm{d}}$ selectivity for BODIPY-ArChol, where the probe is directly ester linked to cholesterol, which is reversed leading to approx. $80 \% \mathrm{~L}_{\mathrm{o}}$ partitioning when a hexyl linker is inserted between probe and cholesterol in the case of BODIPY-Ahx-Chol. The preference for cholesterol rich membrane persists in live cells where changing linker length has a profound impact on the localisation of the probe. Unlike liposomes, BODIPY-Ar-Chol does not stain the membrane of live cells but is directed through the membrane and localises in lipid droplets in HeLa and CHO cell lines. Whereas BODIPYAhx-Chol is retained at the membrane in live cells where it partitions into regions from where the $\mathrm{L}_{\mathrm{d}}$ probe DiD is excluded. The preference for cholesterol rich membrane is confirmed on treatment of HeLa cells with cyclodextrin. Raft like, detergent resistant domains are highly prevalent in cancer cells and BODIPY-Ahx-Chol membrane distribution varied significantly between HeLa and $\mathrm{CHO}$ which is a non-cancer cell. Robust fluorescent probes that can partition into and distinguish raftlike domains in live cells as well as in biophysical models are rare and can facilitate use of advanced microscopy applied to detailed studies into domains and rafts in cells. Ordered lipid domains are particularly prevalent in cancer and in multidrug resistant cells, probes that can be targeted to such domain should be useful in developing insights into such models. Ongoing work will explore whether the principle of extending a long linker to a lipophilic probe can be applied more universally to broader families of fluorescent probes.

\section{Experimental}

\section{Preparation of giant unilamellar vesicles (GUVs)}

Lipid stock solutions were prepared in chloroform. For preparation of $\mathrm{L}_{\mathrm{d}} / \mathrm{L}_{\mathrm{o}}$ phase separated GUVs, 1-2-dioleoyl-sn-glycero-3phosphocholine (DOPC), brain sphingomyelin (BSM) and cholesterol (Chol) were mixed in a molar ratio $4: 4: 2$ to a final concentration of $5 \mathrm{mM}$. For partitioning (confocal fluorescence microscopy) studies BODIPY-Ar-Chol or BODIPY-Ahx-Chol, along with the lipophilic tracer dye DiD, were all included respectively at a concentration of $0.1 \mathrm{~mol} \%$ in lipid content prior to electroformation. DiD is a commercially available lipid stain that is known to associate strongly within the liquiddisordered phase of GUVs. It was therefore chosen in order to identify this phase during confocal fluorescence microscopy experiments. GUVs were formed by electroformation using the Vesicle Prep Pro (VPP) (Nanion Technologies, Munich, Germany). The lipids were added in $1.5 \mu \mathrm{L}$ droplets onto a pair of conductive ITO slides and dried in a desiccator under vacuum for 45 minutes. The ITO slides were carefully placed in contact at an angle to avoid air bubbles. A voltage was then applied and increased over 10 minutes from $0 \mathrm{~V}$ to $3 \mathrm{~V}$ and then held for 125 minutes. The protocol was carried out at $37{ }^{\circ} \mathrm{C}$. Once electroformation was completed, the GUVs were removed, diluted with $0.23 \mathrm{mM}$ glucose solution and $0.5 \%$ agarose solution and deposited on glass coverslides for imaging. For uptake studies, GUVs were prepared as described above by electroformation using DOPC $100 \mathrm{~mol} \%$.

\section{Confocal microscopy of giant unilamellar vesicles (GUVs)}

Fluorescent confocal imaging was carried out using a Leica TSP inverted (DMi8) confocal microscope. A 100-oil immersion objective was used for all measurements. A white light laser was used to excite the dyes. The excitation and emission wavelengths $\left(\lambda_{\text {ex }} / \lambda_{\text {em }}\right)$ were as follows: $503 / 511-570$ for BODIPY-ArChol and BODIPY-Ahx-Chol, and 644/665-700 nm for DiD.

\section{Fluorescence lifetime imaging}

Fluorescence lifetime imaging was carried out using a PicoQuant 100 system attached to Leica TSP inverted (DMi8) confocal microscope using a $100 \times$ oil immersion objective. Each sample was acquired for $120 \mathrm{~s}$ with a $512 \times 512$ resolution. A $503 \mathrm{~nm}$ white light laser was used to excite the GUV samples. Data was analysed using PicoQuant Symphotime software.

\section{Cell culture and imaging}

HeLa cells were purchased from Sigma Aldrich (Ireland) and cultured using MEM media supplemented with $2 \%$ L-glutamine, 1\% MEM non-essential amino acid solution, 10\% fetal bovine serum (FBS) and 1\% penicillin-streptomycin. CHO cells were purchased from ATCC Cell Biology Collection (UK) and cultured 
in a mixture of DMEM media and F-12 Hams media supplemented with $10 \%$ FBS and 1\% penicillin/streptomycin. Both cell lines were grown at $37{ }^{\circ} \mathrm{C}$ with $5 \% \mathrm{CO}_{2}$. Cells were harvested or split at $90 \%$ confluency using $0.25 \%$ trypsin for 5 minutes at $37^{\circ} \mathrm{C}$.

\section{Confocal microscopy for cell imaging}

For imaging, cells were seeded at $7 \times 10^{4}$ cells in $2 \mathrm{~mL}$ culture media on $35 \mathrm{~mm}$ high precision glass-bottom dishes (Ibidi, Germany). BODIPY-Ar-Chol and BODIPY-Ahx-Chol were added to cell media to give a final concentration of $5 \mu \mathrm{M}$ and left to incubate in the absence of light at $37^{\circ} \mathrm{C}$ with $5 \% \mathrm{CO}_{2}$. Cells were washed twice with supplemented PBS (1.1 $\mathrm{mM} \mathrm{MgCl}_{2}$ and $0.9 \mathrm{mM} \mathrm{CaCl}_{2}$ ) prior to imaging. The cells were imaged live using a Leica TSP DMi8 confocal microscope with a $100 \times$ oil immersion objective lens. Cells were excited at $497 \mathrm{~nm}$ and emission was collected between 518-610 nm. Co-staining with DiD was carried out by adding $800 \mathrm{nM}$ DiD in PBS to the cells for 20 minutes at $37^{\circ} \mathrm{C}$ prior to imaging. DiD was excited at $640 \mathrm{~nm}$ and emission was collected between 660-760 $\mathrm{nm}$.

\section{FLIM of live cells}

HeLa and CHO cells were prepared and stained as described for confocal imaging. Live FLIM images were acquired using SymphoTime 200, Picoquant, attached to a Leica TSP DMi8 confocal microscope using a $100 \times$ oil immersion objective. Each FLIM image was acquired for 2 minutes with $512 \times 512$ resolution, at $10 \mathrm{MHz}$ and resolution 16. A $497 \mathrm{~nm}$ laser was used to excite the sample, and emission collected between 520-620 $\mathrm{nm}$. The data was analysed using PicoQuant Symphotime software. Lifetimes were fit to a tri-exponential decay, until a $\chi^{2}$ value of $0.9-1.1$ was achieved.

\section{Synthesis of BODIPY-Ar-COOH (1)}

Synthesis was carried out according to modified procedure. ${ }^{49}$ DCM $(60 \mathrm{~mL})$ was purged with nitrogen for $30 \mathrm{~min}$. To 4 -formylbenzoic acid (500 mg, $3.3 \mathrm{mmol}$ ), 2,4-dimethylpyrrole (453 $\mu \mathrm{L}, 7.45 \mathrm{mmol}$ ) and TFA (cat.) was added and kept at room temperature while stirring for 5 hours. After the 5 hours tetrachlorobenzoquinone ( $p$-chloranil) ( $973 \mathrm{mg}, 3.95 \mathrm{mmol}$ ) in DCM $(20 \mathrm{~mL})$ was added and the reaction mixture was left to stir for 30 minutes followed by the addition of $\mathrm{BF}_{3} \cdot \mathrm{OEt}_{2}(6.4 \mathrm{~mL})$ and $\mathrm{Et}_{3} \mathrm{~N}(6.4 \mathrm{~mL})$. The reaction mixture was left to stir overnight. The crude mixture was washed with water $(2 \times 50 \mathrm{~mL})$, dried over $\mathrm{MgSO}_{4}$ and concentrated to dryness via vacuum. The crude product was purified on a silica gel by column chromatography eluent: DCM/MeOH (30:1). Yield: purple solid, $158.3 \mathrm{mg}$ (0.43 mmol, 13\%). ${ }^{1} \mathrm{H}$ NMR: (600 MHz, DMSO-d ${ }_{6}$ ) $\delta$ (ppm): 9.60 $(\mathrm{t}, 2 \mathrm{H}) ; 9.22(\mathrm{~d}, J=1.8 \mathrm{~Hz}, 2 \mathrm{H}) ; 8.61(\mathrm{~d}, J=1.8 \mathrm{~Hz}, 1 \mathrm{H}) ; 8.42(\mathrm{~d}, J$ $=3 \mathrm{~Hz}, 1 \mathrm{H}) ; 7.97(\mathrm{~d}, J=7.8 \mathrm{~Hz}, 2 \mathrm{H}) ; 7.77-7.75(\mathrm{~m}, 2 \mathrm{H}) ; 7.45(\mathrm{~d}, J$ $=7.8 \mathrm{~Hz}, 2 \mathrm{H}) ; 5.96(\mathrm{~s}, 2 \mathrm{H}) ; 2.52(\mathrm{~s}, 6 \mathrm{H}) ; 1.44(\mathrm{~s}, 6 \mathrm{H}) .{ }^{13} \mathrm{C}$ NMR: (150 MHz, DMSO-d $\left.{ }_{6}\right) \delta(\mathrm{ppm}):$ 155.8, 152.7, 152.6, 143.2, 143.0, $142.6,142.1,141.7,141.3,140.9,140.1,135.3,133.8,131.3$, 130.2 , 130.1, 129.0, 128.2, 127.6, 127.5, 127.0, 124.2, 121.4, 118.9. HR-MS (ESI-TOF) $m / z$ : calculated for $\mathrm{C}_{20} \mathrm{H}_{19} \mathrm{BF}_{2} \mathrm{~N}_{2} \mathrm{O}_{2}$ 369.1512 found 369.1586 .

\section{Synthesis of BODIPY-Ar-Chol (2)}

BODIPY-Ar-COOH (1) (100 mg, $0.272 \mathrm{mmol}$ ) and DMAP (32 mg, $0.0272 \mathrm{mmol}$ ) was dissolved in DCM $(4 \mathrm{~mL})$. Cholesterol (240 mg, $0.599 \mathrm{mmol})$ in DCM $(2 \mathrm{~mL})$ was added to the reaction mixture and stirred at room temperature for $5 \mathrm{~min}$. Following this DCC (70 mg, $0.299 \mathrm{mmol})$ in DCM (2 mL) was added and the reaction mixture was left to stir overnight. The crude mixture was with brine solution, dried over $\mathrm{MgSO}_{4}$ and concentrated to dryness. The crude product was purified on a silica gel by column chromatography eluent: $\mathrm{DCM} / \mathrm{MeOH}$ (30: 1). Yield: orange solid, $78 \mathrm{mg}(0.104 \mathrm{mmol}, 38 \%) .{ }^{1} \mathrm{H}$ NMR: (600 MHz, $\left.\mathrm{CDCl}_{3}\right) \delta(\mathrm{ppm}): 8.18(\mathrm{~d}, J=8.3 \mathrm{~Hz}, 2 \mathrm{H}) ; 7.40$ $(\mathrm{d}, J=8.2 \mathrm{~Hz}, 2 \mathrm{H}) ; 5.98(\mathrm{~s}, 1 \mathrm{H}) ; 5.44(\mathrm{~d}, J=6 \mathrm{~Hz}, 1 \mathrm{H}) ; 4.93-4.87$ $(\mathrm{m}, 1 \mathrm{H}) ; 2.55(\mathrm{~s}, 6 \mathrm{H}) 2.51(\mathrm{~d}, J=7.2,2 \mathrm{H}) ; 2.05-1.92(\mathrm{~m}, 4 \mathrm{H})$; 1.86-1.74 (m, 2H); 1.61-1.55 (m, 2H); 1.52 (s, 6H); 1.50-1.47 (m, $2 \mathrm{H}) ; 1.37$ (s, 6H); 1.29-1.11 (m, 9H); 1.09 (s 4H); 1.05-0.98 (m, $3 \mathrm{H}) ; 0.93(\mathrm{~d}, J=6 \mathrm{~Hz}, 3 \mathrm{H}) ; 0.87(\mathrm{dd}, J=6.5,2.8 \mathrm{~Hz}, 6 \mathrm{H}) ; 0.70(\mathrm{~s}$, 3H). ${ }^{13} \mathrm{C}$ NMR: (150 MHz, $\left.\mathrm{CDCl}_{3}\right) \delta$ (ppm): 165.37, 139.53, 130.32, 128.29, 122.96, 121.46, 75.17, 56.71, 56.16, 50.07, 43.34, 39.52 , 38.22, 37.64, 36.68, 36.19, 35.79, 31.95, 31.90, 28.22, $28.01,27.89,24.30,23.83,22.80,22.55,21.01,19.37,18.72$, 14.55, 11.88. HR-MS (ESI-TOF) $\mathrm{m} / \mathrm{z}$ : calculated for $\mathrm{C}_{47} \mathrm{H}_{63} \mathrm{BF}_{2} \mathrm{~N}_{2} \mathrm{O}_{2} 737.5055$ found 737.5029 .

\section{Synthesis of 4-formylphenyl-Ahx (4)}

4-Formylbenzoic acid (1 g, $6.66 \mathrm{mmol}$ ), EDC (2.55 g, 13.32 $\mathrm{mmol}$ ) and NHS (1.53 g, $13.32 \mathrm{mmol}$ ) was stirred in DCM (50 $\mathrm{mL}$ ) at room temperature for $1 \mathrm{~h}$. Following this methyl 6aminohexanoate $(1.45 \mathrm{~g}, 9.99 \mathrm{mmol})$ in DCM $(2 \mathrm{~mL})$ was added with TEA $(800 \mu \mathrm{L})$ and the reaction mixture was stirred overnight. The crude mixture was washed with $3 \times 50 \mathrm{~mL}$ water, dried over $\mathrm{MgSO}_{4}$ and concentrated to dryness. The reaction was monitored by TLC and NMR and was carried through to the next step without purification. To the reaction product was added $\mathrm{MeOH}(15 \mathrm{~mL})$ and slowly the addition of $0.1 \mathrm{M} \mathrm{LiOH}$ in $\mathrm{MeOH} / \mathrm{H}_{2} \mathrm{O}(3: 1)$. The reaction was stirred at room temperature for $4 \mathrm{~h}$. The reaction mixture was concentrated to dryness and then rehydrated with water. The solution was acidified using conc. $\mathrm{HCl}$ until $\mathrm{pH} 2$ was achieved. The product was obtained via filtration and purified on a silica gel by column chromatography eluent: DCM/MeOH $(80: 20)$. Overall yield for two steps: white solid, $164 \mathrm{mg}$ (0.62 mmol, 9.4\%). ${ }^{1} \mathrm{H}$ NMR: (600 MHz, DMSO-d $\left.{ }_{6}\right) \delta(\mathrm{ppm}): 12.02(\mathrm{~s}, 1 \mathrm{H}) ; 10.08(\mathrm{~s}, 1 \mathrm{H}) ; 8.67(\mathrm{t}, J=$ $12 \mathrm{~Hz}, 1 \mathrm{H}) ; 7.99$ (q, $J=17.8,8.7 \mathrm{~Hz}, 4 \mathrm{H}) ; 3.26$ (q, $J=14.8,7.6$, $2 \mathrm{H}) ; 2.21(\mathrm{t}, J=7.3,2 \mathrm{H}) ; 1.54-1.52(\mathrm{~m}, 4 \mathrm{H}) ; 1.339-1.335(\mathrm{~m}, 2 \mathrm{H})$. ${ }^{13}$ C NMR: (150 MHz, DMSO-d 6 ) $\delta$ (ppm): 193.39, 174.94, 165.73, 140.18, 138.11, 129.85, 128.34, 34.08, 29.18, 26.48, 24.71. HR-MS (ESI-TOF) $m / z$ : calculated for $\mathrm{C}_{14} \mathrm{H}_{17} \mathrm{NO}_{4} 264.1241$ found 264.1236 .

\section{Synthesis of BODIPY-Ahx (5)}

DCM $(30 \mathrm{~mL})$ was purged with nitrogen for $30 \mathrm{~min}$. To 4-formylbenzoic acid (500 mg, $3.3 \mathrm{mmol}$ ), 2,4-dimethylpyrrole (144 $\mu \mathrm{L}, 1.4 \mathrm{mmol}$ ) and TFA (cat.) was added and kept at room temperature while stirring for 5 hours. After the 5 hours 
tetrachlorobenzoquinone ( $p$-chloranil) $(171 \mathrm{mg}, 0.69 \mathrm{mmol})$ in DCM $(20 \mathrm{~mL})$ was added and the reaction mixture was left to stir for 30 minutes followed by the addition of $\mathrm{BF}_{3} \cdot \mathrm{OEt}_{2}(1.74 \mathrm{~mL})$ and $\mathrm{Et}_{3} \mathrm{~N}(1.74 \mathrm{~mL})$. The reaction mixture was left to stir overnight. The crude mixture was washed with water $(2 \times 50 \mathrm{~mL})$, dried over $\mathrm{MgSO}_{4}$ and concentrated to dryness via vacuum. The crude product was purified on a silica gel by column chromatography eluent: $\mathrm{DCM} / \mathrm{MeOH}(30: 1)$ followed by $\mathrm{DCM} / \mathrm{MeOH}$ (90 : 10). Yield: orange solid, $37.6 \mathrm{mg}(0.078 \mathrm{mmol}, 13.4 \%) .{ }^{1} \mathrm{H}$

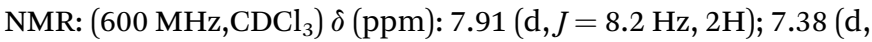
$J=8.16 \mathrm{~Hz}, 2 \mathrm{H}) ; 6.30(\mathrm{t}, J=5.58,1 \mathrm{H}) ; 5.97(\mathrm{~s}, 1 \mathrm{H}) ; 3.51-3.48(\mathrm{~m}$, $2 \mathrm{H}) ; 2.54(\mathrm{~s}, 1 \mathrm{H}) ; 2.39(\mathrm{t}, J=7.9 \mathrm{~Hz}, 2 \mathrm{H}) ; 1.70-1.67(\mathrm{~m}, 4 \mathrm{H}) ; 1.48-$ $1.47(\mathrm{~m}, 2 \mathrm{H}) ; 1.35(\mathrm{~s}, 6 \mathrm{H}) .{ }^{13} \mathrm{C} \mathrm{NMR}$ was not obtained due to poor solubility. HR-MS (ESI-TOF) $m / z$ : calculated for $\mathrm{C}_{26} \mathrm{H}_{32} \mathrm{BF}_{2} \mathrm{~N}_{3} \mathrm{O}_{3} 482.2412$ found 482.2427 .

\section{Synthesis of BODIPY-Ahx-Chol (6)}

To a stirred solution of $5(32.6 \mathrm{mg}, 0.067 \mathrm{mmol})$ and DMAP $(8.1 \mathrm{mg}, 0.0067 \mathrm{mmol})$ in DCM (4 mL), a solution of cholesterol (51 mg, $0.134 \mathrm{mmol})$ in DCM $(2 \mathrm{~mL})$ was added. The reaction mixture was stirred for $5 \mathrm{~min}$ at room temperature. A solution of DCC (15.2 mg, $0.073 \mathrm{mmol})$ in DCM $(2 \mathrm{~mL})$ was added and the mixture was stirred at room temperature overnight. The crude mixture was washed with brine solution, dried over $\mathrm{MgSO}_{4}$ and concentrated to dryness via vacuum. The crude product was purified on silica gel by column chromatography eluent: DCM/ $\mathrm{MeOH}$ (90: 10). Yield: orange solid, $22.9 \mathrm{mg}$ (0.026 mmol, 40.2\%). ${ }^{1} \mathrm{H}$ NMR: $\left(600 \mathrm{MHz}, \mathrm{CDCl}_{3}\right) \delta(\mathrm{ppm}): 7.94(\mathrm{~d}, J=8.2 \mathrm{~Hz}$, $2 \mathrm{H}) ; 7.39(\mathrm{~d}, J=8.2 \mathrm{~Hz}, 2 \mathrm{H}) ; 6.38(\mathrm{t}, J=5.46 \mathrm{~Hz}, 1 \mathrm{H}) ; 5.98(\mathrm{~s}$, $2 \mathrm{H}) ; 5.36(\mathrm{~d}, J=4.8 \mathrm{~Hz}, 1 \mathrm{H}) ; 4.63-4.57(\mathrm{~m}, 1 \mathrm{H}) ; 3.67-3.64(\mathrm{~m}$, $2 \mathrm{H}) ; 3.52(\mathrm{q}, J=14.2,7 \mathrm{~Hz}, 2 \mathrm{H}) ; 2.55(\mathrm{~s}, 6 \mathrm{H}) ; 2.34-2.30(\mathrm{~m} 4 \mathrm{H})$; 2.02-1.91 (m, 2H); 1.86-1.79 (m, 3H); 1.72-1.66 (m, 4H); 1.50$1.40(\mathrm{~m}, 7 \mathrm{H}) ; 1.35(\mathrm{~s}, 6 \mathrm{H}) ; 1.25(\mathrm{~s}, 6 \mathrm{H}) ; 1.17-1.07(\mathrm{~m}, 7 \mathrm{H}) ; 1.01(\mathrm{~s}$, $3 \mathrm{H}) ; 0.91(\mathrm{~d}, J=6.7 \mathrm{~Hz}, 3 \mathrm{H}) ; 0.86(\mathrm{dd}, J=6.5,2.9 \mathrm{~Hz}, 7 \mathrm{H}) ; 0.66$ (s, 3H). ${ }^{13} \mathrm{C}$ NMR: (150 MHz, $\left.\mathrm{CDCl}_{3}\right) \delta$ (ppm): 173.23, 166.56, 155.93, 142.92, 140.35, 139.60, 138.26, 135.22, 131.07, 128.47, $127.77,122.78,121.46,76.81,74.06,56.63,56.13,49.99,42.30$, $39.71,39.52,38.18,37.00,36.61,36.18,35.80,34.30,31.84$, $29.71,28.97,28.24,28.02,27.82,26.23,24.26,24.16,23.83$, $22.83,22.57,21.02,19.32,18.72,14.64,14.13,11.85$. HR-MS (ESI-TOF) $m / z$ : calculated for $\mathrm{C}_{53} \mathrm{H}_{74} \mathrm{BF}_{2} \mathrm{~N}_{3} \mathrm{O}_{3} 850.5852$ found 850.5870 .

\section{Conflicts of interest}

The authors declare no competing financial interest.

\section{Acknowledgements}

Supported by Science Foundation Ireland under Grant No. [14/ IA/2488] and [18/TIDA/5862]. The Programme for Research in Third Level Institutions (PRTLI) Cycle 4 and 5 is acknowledged for instrumentation under the NBIPI and NRF at Dublin City University. The PRTLI is co-funded through the European Regional Development Fund (ERDF), part of the European Union Structural Funds Programme 2007-2015. Professor R
O'Kennedy, School of Biotechnology, DCU, is gratefully acknowledged for access to cell culture facilities.

\section{Notes and references}

1 L. Anchisi, S. Dessi, A. Pani and A. Mandas, Cholesterol Homeostasis: A Key to Prevent or Slow down Neurodegeneration, Front. Physiol., 2013, 3, 486.

2 D. Marsh, Cholesterol-Induced Fluid Membrane Domains: A Compendium of Lipid-Raft Ternary Phase Diagrams, Biochim. Biophys. Acta, Biomembr., 2009, 1788(10), 21142123.

3 D. Lingwood and K. Simons, Lipid Rafts as a MembraneOrganizing Principle, Science, 2010, 327(5961), 46-50.

4 E. Sevcsik, M. Brameshuber, M. Fölser, J. Weghuber, A. Honigmann and G. J. Schütz, GPI-Anchored Proteins Do Not Reside in Ordered Domains in the Live Cell Plasma Membrane, Nat. Commun., 2015, 6, 6969.

5 M. L. Kraft, Plasma Membrane Organization and Function: Moving Past Lipid Rafts, Mol. Biol. Cell, 2013, 24(18), 27652768.

6 K. Simons and R. Ehehalt, Cholesterol, Lipid Rafts, and Disease, J. Clin. Invest., 2002, 110(5), 597-603.

7 K. Simons and G. Van Meer, Lipid Sorting in Epithelial Cells, Biochemistry, 1988, 27(17), 6197-6202.

$8 \mathrm{~K}$. Simons and E. Ikonen, Functional Rafts in Cell Membranes, Nature, 1997, 387(6633), 569-572.

9 Z. Korade and A. K. Kenworthy, Lipid Rafts, Cholesterol, and the Brain, Neuropharmacology, 2008, 55(8), 1265-1273.

10 L. J. Pike, The Challenge of Lipid Rafts, J. Lipid Res., 2009, 50(suppl.), S323-S328.

11 F. A. Heberle and G. W. Feigenson, Phase Separation in Lipid Membranes, Cold Spring Harbor Perspect. Biol., 2011, 3(4), a004630.

12 G. de Wit, J. S. H. Danial, P. Kukura and M. I. Wallace, Dynamic Label-Free Imaging of Lipid Nanodomains, Proc. Natl. Acad. Sci. U. S. A., 2015, 112(40), 12299-12303.

13 F. R. Moss and S. G. Boxer, Atomic Recombination in Dynamic Secondary Ion Mass Spectrometry Probes Distance in Lipid Assemblies: A Nanometer Chemical Ruler, J. Am. Chem. Soc., 2016, 138(51), 16737-16744.

14 Y. Shan and H. Wang, The Structure and Function of Cell Membranes Examined by Atomic Force Microscopy and Single-Molecule Force Spectroscopy, Chem. Soc. Rev., 2015, 44(11), 3617-3638.

15 A. Honigmann, V. Mueller, H. Ta, A. Schoenle, E. Sezgin, S. W. Hell and C. Eggeling, Scanning STED-FCS Reveals Spatiotemporal Heterogeneity of Lipid Interaction in the Plasma Membrane of Living Cells, Nat. Commun., 2014, 5, 5412.

16 P. Walde, K. Cosentino, H. Engel and P. Stano, Giant Vesicles: Preparations and Applications, ChemBioChem, 2010, 11(7), 848-865.

17 S. L. Veatch and S. L. Keller, Separation of Liquid Phases in Giant Vesicles of Ternary Mixtures of Phospholipids and Cholesterol, Biophys. J., 2003, 85(5), 3074-3083. 
18 M. R. Dent, I. López-Duarte, C. J. Dickson, N. D. Geoghegan, J. M. Cooper, I. R. Gould, R. Krams, J. A. Bull, N. J. Brooks and M. K. Kuimova, Imaging Phase Separation in Model Lipid Membranes through the Use of BODIPY Based Molecular Rotors, Phys. Chem. Chem. Phys., 2015, 17(28), 18393-18402.

19 T. Baumgart, G. Hunt, E. R. Farkas, W. W. Webb and G. W. Feigenson, Fluorescence Probe Partitioning between Lo/Ld Phases in Lipid Membranes, Biochim. Biophys. Acta, Biomembr., 2007, 1768(9), 2182-2194.

20 G. A. Crosby and J. N. Demas, Measurement of Photoluminescence Quantum Yields. Review, J. Phys. Chem., 1971, 75(8), 991-1024.

21 E. Sezgin, I. Levental, M. Grzybek, G. Schwarzmann, V. Mueller, A. Honigmann, V. N. Belov, C. Eggeling, Ü. Coskun, K. Simons, et al., Partitioning, Diffusion, and Ligand Binding of Raft Lipid Analogs in Model and Cellular Plasma Membranes, Biochim. Biophys. Acta, Biomembr., 2012, 1818(7), 1777-1784.

22 H. C. Daly, G. Sampedro, C. Bon, D. Wu, G. Ismail, R. A. Cahill and D. F. O'Shea, BF2-Azadipyrromethene NIREmissive Fluorophores with Research and Clinical Potential, Eur. J. Med. Chem., 2017, 135, 392-400.

23 M. Grossi, M. Morgunova, S. Cheung, D. Scholz, E. Conroy, M. Terrile, A. Panarella, J. C. Simpson, W. M. Gallagher and D. F. O'Shea, Lysosome Triggered near-Infrared Fluorescence Imaging of Cellular Trafficking Processes in Real Time, Nat. Commun., 2016, 7, 10855.

24 L. Dura, M. Wächtler, S. Kupfer, J. Kübel, J. Ahrens, S. Höfler, M. Bröring, B. Dietzek and T. Beweries, Photophysics of BODIPY Dyes as Readily-Designable Photosensitisers in Light-Driven Proton Reduction, Inorganics, 2017, 5(2), 21.

25 Q. Tang, W. Si, C. Huang, K. Ding, W. Huang, P. Chen, Q. Zhang and X. Dong, An Aza-BODIPY Photosensitizer for Photoacoustic and Photothermal Imaging Guided Dual Modal Cancer Phototherapy, J. Mater. Chem. B, 2017, 5(8), 1566-1573.

26 M. Strobl, A. Walcher, T. Mayr, I. Klimant and S. M. Borisov, Trace Ammonia Sensors Based on Fluorescent NearInfrared-Emitting Aza-BODIPY Dyes, Anal. Chem., 2017, 89(5), 2859-2865.

27 Y. Fu and N. S. Finney, Small-Molecule Fluorescent Probes and Their Design, RSC Adv., 2018, 8(51), 29051-29061.

28 G. Ulrich, R. Ziessel and A. Harriman, The Chemistry of Fluorescent Bodipy Dyes: Versatility Unsurpassed, Angew. Chem., Int. Ed., 2008, 47(7), 1184-1201.

29 F. Nastasi, F. Puntoriero, S. Campagna, J.-H. Olivier and R. Ziessel, Hybrid Complexes: Pt(II)-Terpyridine Linked to Various Acetylide-Bodipy Subunits, Phys. Chem. Chem. Phys., 2010, 12(27), 7392-7402.

30 A. Loudet and K. Burgess, BODIPY Dyes and Their Derivatives: Syntheses and Spectroscopic Properties, Chem. Rev., 2007, 107(11), 4891-4932.

31 R. Ziessel, G. Ulrich and A. Harriman, The Chemistry of Bodipy: A New El Dorado for Fluorescence Tools, New J. Chem., 2007, 31(4), 496-501.
32 R. Ziessel, L. Bonardi and G. Ulrich, Boron Dipyrromethene Dyes: A Rational Avenue for Sensing and Light Emitting Devices, Dalton Trans., 2006, (no. 23), 2913-2918.

33 T. Kowada, H. Maeda and K. Kikuchi, BODIPY-Based Probes for the Fluorescence Imaging of Biomolecules in Living Cells, Chem. Soc. Rev., 2015, 44(14), 4953-4972.

34 Y. Ni and J. Wu, Far-Red and near Infrared BODIPY Dyes: Synthesis and Applications for Fluorescent $\mathrm{pH}$ Probes and Bio-Imaging, Org. Biomol. Chem., 2014, $12(23), 3774$.

35 L. Yang, Y. Liu, W. Liu, C. Ma, C. Zhang and Y. Li, Divinyl BODIPY Derivative: Synthesis, Photophysical Properties, Crystal Structure, Photostability and Bioimaging, Bioorg. Med. Chem. Lett., 2015, 25(24), 5716-5719.

36 N. Deepika, C. S. Devi, Y. P. Kumar, K. L. Reddy, P. V. Reddy, D. A. Kumar, S. S. Singh and S. Satyanarayana, DNA-Binding, Cytotoxicity, Cellular Uptake, Apoptosis and Photocleavage Studies of $\mathrm{Ru}(\mathrm{II})$ Complexes, J. Photochem. Photobiol., B, 2016, 160, 142-153.

37 X.-D. Jiang, R. Gao, Y. Yue, G.-T. Sun and W. Zhao, A NIR BODIPY Dye Bearing 3,4,4a-Trihydroxanthene Moieties, Org. Biomol. Chem., 2012, 10(34), 6861.

38 T. Papalia, R. Lappano, A. Barattucci, A. Pisano, G. Bruno, M. F. Santolla, S. Campagna, P. D. Marco, F. Puntoriero, E. M. D. Francesco, et al., A Bodipy as a Luminescent Probe for Detection of the $\mathrm{G}$ Protein Estrogen Receptor (GPER), Org. Biomol. Chem., 2015, 13(42), 10437-10441.

39 C. Staudinger, J. Breininger, I. Klimant and S. M. Borisov, Near-Infrared Fluorescent Aza-BODIPY Dyes for Sensing and Imaging of $\mathrm{pH}$ from the Neutral to Highly Alkaline Range, Analyst, 2019, 144(7), 2393-2402.

40 Z. Liu, S. G. Thacker, S. Fernandez-Castillejo, E. B. Neufeld, A. T. Remaley and R. Bittman, Synthesis of Cholesterol Analogues Bearing BODIPY Fluorophores by Suzuki or Liebeskind-Srogl Cross-Coupling and Evaluation of Their Potential for Visualization of Cholesterol Pools, ChemBioChem, 2014, 15(14), 2087-2096.

41 M. Hölttä-Vuori, R.-L. Uronen, J. Repakova, E. Salonen, I. Vattulainen, P. Panula, Z. Li, R. Bittman and E. Ikonen, BODIPY-Cholesterol: A New Tool to Visualize Sterol Trafficking in Living Cells and Organisms, Traffic, 2008, 9(11), 1839-1849.

42 Z. Li, E. Mintzer and R. Bittman, First Synthesis of Free Cholesterol-BODIPY Conjugates, J. Org. Chem., 2006, 71(4), 1718-1721.

43 M. J. Sarmento, S. N. Pinto, A. Coutinho, M. Prieto and F. Fernandes, Accurate Quantification of Inter-Domain Partition Coefficients in GUVs Exhibiting Lipid Phase Coexistence, RSC Adv., 2016, 6(71), 66641-66649.

44 A. S. Klymchenko and R. Kreder, Fluorescent Probes for Lipid Rafts: From Model Membranes to Living Cells, Chem. Biol., 2014, 21(1), 97-113.

45 Y. Niko, P. Didier, Y. Mely, G. Konishi and A. S. Klymchenko, Bright and Photostable Push-Pull Pyrene Dye Visualizes Lipid Order Variation between Plasma and Intracellular Membranes, Sci. Rep., 2016, 6, 18870.

46 F. S. Ariola, Z. Li, C. Cornejo, R. Bittman and A. A. Heikal, Membrane Fluidity and Lipid Order in Ternary Giant 
Unilamellar Vesicles Using a New Bodipy-Cholesterol Derivative, Biophys. J., 2009, 96(7), 2696-2708.

47 J. M. Kwiatek, D. M. Owen, A. Abu-Siniyeh, P. Yan, L. M. Loew and K. Gaus, Characterization of a New Series of Fluorescent Probes for Imaging Membrane Order, PLoS One, 2013, 8(2), e52960.

48 Y. Wu, M. Štefl, A. Olzyńska, M. Hof, G. Yahioglu, P. Yip, D. R. Casey, O. Ces, J. Humpolíčková and M. K. Kuimova, Molecular Rheometry: Direct Determination of Viscosity in Lo and Ld Lipid Phases via Fluorescence Lifetime Imaging, Phys. Chem. Chem. Phys., 2013, 15(36), 14986-14993.

49 C. Wei, R. Wang, L. Wei, L. Cheng, Z. Li, Z. Xi and L. Yi, OFluorination of Aromatic Azides Yields Improved AzidoBased Fluorescent Probes for Hydrogen Sulfide: Synthesis, Spectra, and Bioimaging, Chem.-Asian J., 2014, 9(12), 35863592.

50 J. Karolin, L. B.-A. Johansson, L. Strandberg and T. Ny, Fluorescence and Absorption Spectroscopic Properties of Dipyrrometheneboron Difluoride (BODIPY) Derivatives in Liquids, Lipid Membranes, and Proteins, J. Am. Chem. Soc., 1994, 116(17), 7801-7806.

51 A. Martin, A. Byrne, C. Dolan, R. J. Forster and T. E. Keyes, Solvent Switchable Dual Emission from a Bichromophoric ruthenium-BODIPY Complex, Chem. Commun., 2015, 51(87), 15839-15841.

52 M. Aureli, S. Grassi, S. Sonnino and A. Prinetti, Isolation and Analysis of Detergent-Resistant Membrane Fractions, Methods Mol. Biol., 2016, 1376, 107-131.

53 J. M. Crane and L. K. Tamm, Role of Cholesterol in the Formation and Nature of Lipid Rafts in Planar and Spherical Model Membranes, Biophys. J., 2004, 86(5), 29652979.

54 J. R. Silvius, Role of Cholesterol in Lipid Raft Formation: Lessons from Lipid Model Systems, Biochim. Biophys. Acta, Biomembr., 2003, 1610(2), 174-183.

55 H. M. McConnell and M. Vrljic, Liquid-Liquid Immiscibility in Membranes, Annu. Rev. Biophys. Biomol. Struct., 2003, 32, 469-492.

56 T. P. W. McMullen, R. N. A. H. Lewis and R. N. McElhaney, Cholesterol-phospholipid Interactions, the Liquid-Ordered Phase and Lipid Rafts in Model and Biological Membranes, Curr. Opin. Colloid Interface Sci., 2004, 8(6), 459-468.

57 J. Huang and G. W. Feigenson, A Microscopic Interaction Model of Maximum Solubility of Cholesterol in Lipid Bilayers, Biophys. J., 1999, 76(4), 2142-2157.

58 D. O'Connor, A. Byrne, C. Dolan and T. E. Keyes, Phase Partitioning, Solvent-Switchable BODIPY Probes for High Contrast Cellular Imaging and FCS, New J. Chem., 2018, 42(5), 3671-3682.
59 D. I. Mundy, Dual Control of Caveolar Membrane Traffic by Microtubules and the Actin Cytoskeleton, J. Cell Sci., 2002, 115(22), 4327-4339.

60 D. I. Mundy, W. P. Li, K. Luby-Phelps and R. G. Anderson, Caveolin Targeting to Late Endosome/lysosomal Membranes Is Induced by Perturbations of Lysosomal $\mathrm{pH}$ and Cholesterol Content, Mol. Biol. Cell, 2012, 23(5), 864880.

61 C. G. Hansen, G. Howard and B. J. Nichols, Pacsin 2 Is Recruited to Caveolae and Functions in Caveolar Biogenesis, J. Cell Sci., 2011, 124(16), 2777-2785.

62 V. Lladó, D. J. López, M. Ibarguren, M. Alonso, J. B. Soriano, P. V. Escribá and X. Busquets, Regulation of the Cancer Cell Membrane Lipid Composition by NaCHOleate: Effects on Cell Signaling and Therapeutical Relevance in Glioma, Biochim. Biophys. Acta, 2014, 1838(6), 1619-1627.

63 N. Bernardes and A. M. Fialho, Perturbing the Dynamics and Organization of Cell Membrane Components: A New Paradigm for Cancer-Targeted Therapies, Int. J. Mol. Sci., 2018, 19(12), 3871.

64 S. Zalba and T. L. M. Ten Hagen, Cell Membrane Modulation as Adjuvant in Cancer Therapy, Cancer Treat. Rev., 2017, 52, 48-57.

65 E. B. Neufeld, A. M. Cooney, J. Pitha, E. A. Dawidowicz, N. K. Dwyer, P. G. Pentchev and E. J. Blanchette-Mackie, Intracellular Trafficking of Cholesterol Monitored with a Cyclodextrin, J. Biol. Chem., 1996, 271(35), 21604-21613.

66 M. Fukasawa, M. Nishijima, H. Itabe, T. Takano and K. Hanada, Reduction of Sphingomyelin Level without Accumulation of Ceramide in Chinese Hamster Ovary Cells Affects Detergent-Resistant Membrane Domains and Enhances Cellular Cholesterol Efflux to Methyl-Beta -Cyclodextrin, J. Biol. Chem., 2000, 275(44), 34028-34034.

67 M. Hao, S. Mukherjee, Y. Sun and F. R. Maxfield, Effects of Cholesterol Depletion and Increased Lipid Unsaturation on the Properties of Endocytic Membranes, J. Biol. Chem., 2004, 279(14), 14171-14178.

68 S. Gallois-Montbrun, R. K. Holmes, C. M. Swanson, M. Fernandez-Ocana, H. L. Byers, M. A. Ward and M. H. Malim, Comparison of Cellular Ribonucleoprotein Complexes Associated with the APOBEC3F and APOBEC3G Antiviral Proteins, J. Virol., 2008, 82(11), 5636-5642.

69 S. Nishimura, K. Ishii, K. Iwamoto, Y. Arita, S. Matsunaga, Y. Ohno-Iwashita, S. B. Sato, H. Kakeya, T. Kobayashi and M. Yoshida, Visualization of Sterol-Rich Membrane Domains with Fluorescently-Labeled Theonellamides, PLoS One, 2013, 8(12), e83716.

70 F. R. Maxfield, Plasma Membrane Microdomains, Curr. Opin. Cell Biol., 2002, 14(4), 483-487. 